\title{
Online Appendix: How Do Providers Respond to Changes in Public Health Insurance Coverage? Evidence from Adult Medicaid Dental Benefits
}

\author{
Thomas Buchmueller, Sarah Miller and Marko Vujicic
}

\section{A Alternative Measures of Dental Coverage (Appendix)}

In our main analysis, we evaluate the effect of states adding or dropping "full" dental benefits only. Full dental benefits cover preventive, restorative, and emergency dental services and apply to all adult Medicaid beneficiaries. In this section, we explore the extent to which limited and emergency dental coverage policies affect provider behavior. In contrast to full dental benefits, limited dental coverage either a) does not apply to all adult Medicaid beneficiaries (e.g., coverage is only available to pregnant women) or b) does not cover common types of dental care (e.g., restorative services are not covered). Emergency dental coverage covers only emergency tooth extraction. Often, emergency dental care is conducted in the emergency department of hospitals, rather than at dentists' offices (see, e.g., Choi 2012).

To explore the effects of limited and emergency dental coverage, we estimate our main specification (equation (1) in the main text) but also include binary variables Limited and Emergency that equal 1 if the state provides limited or emergency dental benefits, respectively. These classifications are determined by the American Dental Association. Column 4 presents the significance levels of a test for which the null hypothesis is that all three effects are the same; i.e., it tests whether the coefficients are statistically significantly different across Full, Limited, and Emergency coverage. 
The results are presented in Appendix Table 1. We find that limited and emergency dental services have statistically significant effects on dentist participation in the Medicaid program, although the effects are smaller than those observed when states add full coverage. Limited and emergency dental benefits increase the probability a dentist has any publicly insured patient by 6 and 5 percentage points respectively, while full benefits are associated with an increase of 9 percentage points. Full dental benefits increase the percent of a dentists' patients who are publicly insured by 2.5 percentage points, limited benefits result in an increase of 1.7 percentage points, and emergency benefits result in an increase of 1.1 percentage points. Similarly, full dental benefits increase the percent of gross receipts received from the government by 2.8 percentage points, limited dental benefits increase this percent by 1.9 percentage points, and emergency dental benefits increase this by a statistically insignificant 0.65 percentage points.

We find no significant effects of limited or emergency dental coverage on the total supply of visits or the number of dental hygienist visits, although the we do find that limited coverage increases the number of visits to publicly insured patients. We do not find that limited or emergency dental benefits significantly increase in the number of hours dentists spend working per week, although we do find a significant increase in dentists' income associated with limited dental benefits. This increase in income associated with limited dental coverage for adult Medicaid recipients is smaller than what we find for full coverage. We also do not

find any effect of limited or emergency dental coverage on hygienist employment or wait times. Overall, we conclude that limited and emergency dental benefits have only a small impact on dentists' behavior relatively to full dental benefits.

\section{B Additional Estimates (Appendix)}

In the main text, we only report the coefficient on our outcome of interest. In Appendix Table 2, we report the coefficients on the other independent included in the model with controls for selected outcomes. In this table, the dependent variables are listed in the first row, and the independent variables are listed in the first column. All models include state 
and year fixed effects (not reported), and the indicator for full dental coverage (reported in the main text). Estimates of the full model for other outcomes are available upon request.

The first four rows present the coefficients on variables describing the dentist and his or her practice. Being a general practitioner is associated with seeing a smaller percentage of public patients, providing fewer visits each week as well as fewer emergency/walk-in visits, spending more hours seeing patients, lower income, and a higher likelihood of employing a hygienist. Dentists with an ownership stake in the practice see smaller percentage of public patients than other dentists, provide more visits per week and more emergency/walk-in visits, work longer hours, have higher incomes, and are less likely to employ a hygienist. The number of dentists affiliated with a practice is positively correlated with the percent of patients with public insurance, the number of emergency/walk-in visits per week, the number of hours spent treating patients per week, income, and the probability of employing a hygienist. More experience (years practicing) is associated with a lower percentage of public insured patients, fewer total visits and fewer emergency/walk-in visits, fewer hours worked per week, and lower income.

The next four rows present the coefficients on the control variables describing the characteristics of the county in which the dentist practices. The county poverty rate is positively correlated with the percent of patients with public insurance, total number of visits, and number of emergency/walk-in visits. The fraction of the county who is black is negatively associated with the percent of patients with public insurance, the number of total visits, and the number of emergency/walk-in visits. The unemployment rate of the county is positively correlated with the number of emergency/walk-in visits and negatively correlated with a dentist's income. The fraction of the county population who are under 18 has strong positive correlations with the percent of patients who have public insurance, the number of total visits, the number of emergency or walk-in visits, and the number of hours spent treating patients.

The final two rows present the coefficients on control variables describing the characteristics of the state in which the dentist practices. The percent uninsured in the state is negatively correlated with the percent of patients that a dentist sees who are publicly 
insured, and the gross state product is positively correlated with hours worked.

Additional tables present more supplementary results. In Appendix Table 3 we present our main results with a percentile-t clustered bootstrap confidence interval. We provide confidence intervals associated with the standard errors discussed in the main text for reference in Columns 1 and 2. The inference conducted using this bootstrap procedure is similar to that conducted in the main text. In Appendix Table 4 we present results of placebo tests that are discussed in the main text in Section 4.5.

In Appendix Table 5 we present results separately for states that added and states that dropped adult Medicaid dental benefits. This table explores whether the effects of dropping coverage are similar to the effects of adding coverage. With the exception of the effect on the percent of patients who are publicly insured, we cannot reject the null hypothesis that the effects of adding and dropping coverage are symmetric.

In the Appendix Table 6 we present results that are stratified based on the likelihood that a dental practice has a marginal cost curve similar to $M C_{3}$ in Figure 3 from the main text. First, we stratify the sample based on the predicted fraction of patients who are publicly insured. We estimate a model that predicts the percent of practice's patients that has public insurance as a function of geographic characteristics (the poverty rate and the demographic composition of the county where the practice is located) and characteristics of the practice itself (whether the dentist is a GP, number of years in practice, number of dentists in the practice). We then sort the data by the predicted values from this regression. Dentists who are predicted to have very few publicly insured patients (25th percentile or lower) we consider as being likely to have cost curves like $M C_{1}$ or $M C_{2}$, while those who are predicted to have more publicly insured patients (above the 25 th percentile) we consider to be more likely to have cost curves like $M C_{3}$. These results are presented in Columns 1 and 2. We find significantly larger effects for dentists in practices that are more likely to be affected (i.e., more likely to have cost curves like $M C_{3}$ ). In Columns 3 and 4 of Appendix Table 6, we present results from an analysis that stratifies the sample based on the whether or not a dentist accepts Medicaid. We find stronger effects among dentists that do accept Medicaid relative to those that do not. We find that the effects are largest among dentists who accept 
Medicaid patients, consistent with our model.

Finally, in Appendix Table 7 we explore heterogeneous effects by reimbursement rate. We conduct this analysis using the ratio between Medicaid's reimbursement rate for this procedure and the average price paid by private insurers in the state as represented in the Fair Health data. We estimate our main specification but include the reimbursement rate measure and the interaction between the reimbursement rate measure and the indicator variable $F_{u l l}$. If the coefficient on the interaction term is economically and statistically significant, it suggests that dentists practicing in states with higher reimbursement rates respond differently to changes in Medicaid coverage. We find that the effect of the policy change on dental labor supply differs significantly between high and low reimbursement rate environments, but do not detect differential effects for other outcomes.

\section{Event Study Figures of the Effect of Dental Cover- age (Appendix)}

Figure 1 provides such descriptive evidence of how changes to state Medicaid policy affect dentists' behavior. This "event study" figure displays the change in our main outcome variables relative to the year when dental services were added or dropped to adult Medicaid benefits. For states that both added or dropped Medicaid dental benefits, we include data from the first change in policy only. The x-axis displays the years from the policy change, with the policy change recorded as year "0." Both states that dropped and added these benefits are displayed on the same graph, but arranged such that the change in policy is always expressed as an adoption (rather than a drop) of benefits. That is, for states that dropped benefits, time is expressed as running from 5 to -5 (from right to left); for states that added benefits, time is expressed as running from -5 to 5 (left to right).

The panel (a) displays the change in the percent of patients who are publicly insured over time. When states cover full dental benefits, this percent is higher, suggesting that expanding coverage increases dentists' participation in the program. Panel (b) displays the 
total number of visits and panel (c) displays the number of visits to publicly-insured patients hours. Both appear to substantially increase when states add dental benefits to Medicaid coverage. Hours spent treating patients (panel $(\mathrm{d})$ ) and the number of full-time hygienists employed (panel (e)) increase accordingly, suggesting that these are two mechanisms by which providers are able to expand capacity. Income, presented in panel (f), does not noticeably increase following the adoption of Medicaid dental benefits, although the variance of the measure appears to be high. Finally, the number of days it takes to get an appointment (g) and the average amount of time spent in the waiting room (h) both appear to increase significantly when states have provide full dental benefits to Medicaid recipients.

\section{Construction of county-level adult Medicaid cover- age estimates (Appendix)}

In our discussion of the results, we report estimates that scale the reduced form effects of adding full dental benefits to adult Medicaid coverage by the average fraction of the adult population that has Medicaid coverage. The purpose of this scaling is to provide context for interpreting the reduced form effects, as well as translating these estimates into the effect of an incremental increase in dental insurance coverage (see Section 3.2 in the main text). In this appendix section, we describe how we calculate the fraction of adults in each county who are Medicaid beneficiaries.

For the years 2008 through 2011, we are able to directly calculate the fraction of the adult population that is covered by Medicaid using the American Community Survey (ACS). The ACS provides geographic information by Public Use Microdata Area on Medicaid coverage, and we map these data to counties using a crosswalk provided by the Missouri Census Data Center. $^{1}$

The ACS only included questions related to insurance status beginning in 2008. For years prior to 2008, we construct county level Medicaid coverage figures using state-level Medicaid

\footnotetext{
${ }^{1}$ Downloaded from http://mcdc2.missouri.edu/websas/geocorr2k.html on May 16, 2013.
} 
enrollment information and the 2008 county-level Medicaid beneficiary information from the ACS. To do this, we assume that the county-to-state Medicaid beneficiary ratio remains fixed; that is, we assume that each county maintains the same percent of total state Medicaid beneficiaries, even if the total number of Medicaid beneficiares fluctuates at the state level. We first construct the ratio as

$$
\widehat{\text { Ratio }}=\frac{\# \text { Adult Medicaid Recipients in County in } 2008_{c s}}{\# \text { Adult Medicaid Recipients in State in } 2008_{s}}
$$

We use data on the annual number of adult Medicaid recipients by state from the Medicaid Statistical Information System (MSIS) State Summary data reports. ${ }^{2}$ These documents report the total number of adult Medicaid enrollees by state for each year. We map this to the county using our constructed ratio as

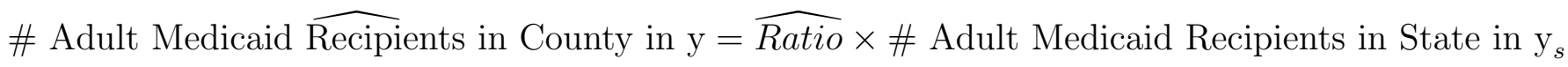

where y ranges from 1999 to 2007. We then divide our estimate of the \# of Adult Medicaid Recipients in County in y by the Census population count of adults to obtain the estimated fraction of the adult population who are Medicaid beneficiaries. In the text, we use this fraction to scale our reduced form estimates. Our results are similar if we instead use both $\widehat{\text { Ratio }}$ and other county demographic and economic characteristics (percent in poverty, fraction under age 18, fraction black, unemployment rate) in a regression model to predict the fraction of adult Medicaid recipients in a county.

\footnotetext{
${ }^{2}$ Downloaded from http://www.cms.gov/Research-Statistics-Data-and-Systems/Computer-Data-andSystems/MedicaidDataSourcesGenInfo/index.html on May 16, 2013.
} 
Figure 1: Change in Medicaid Adult Dental Coverage: Event Study Figures for Main Outcome Variables

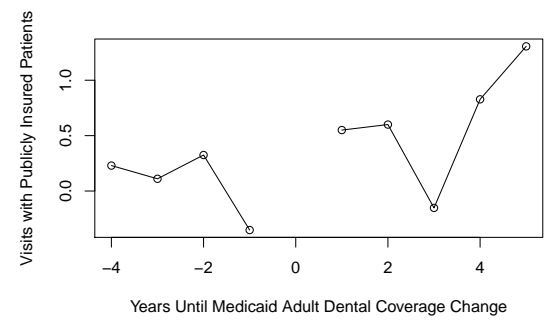

(a) Percent of Patients

Publicly Insured

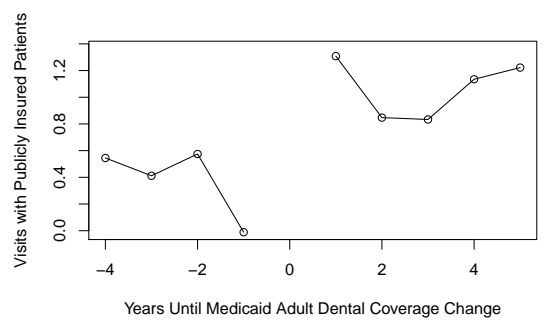

(c) Visits to Publicly-Insured Patients per Week

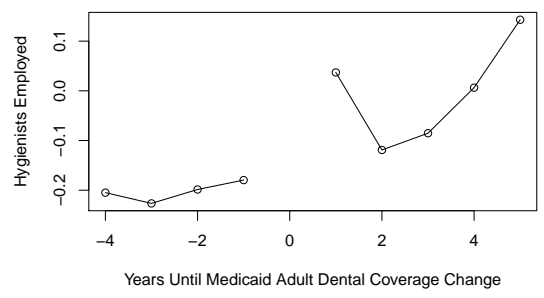

(e) \# Hygienists

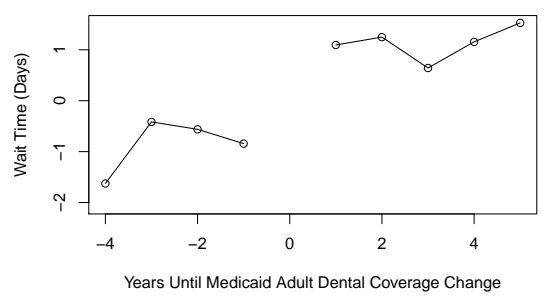

(g) Wait Time for Appt In Days

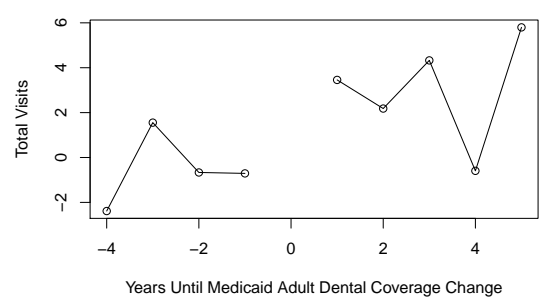

(b) Total Visits

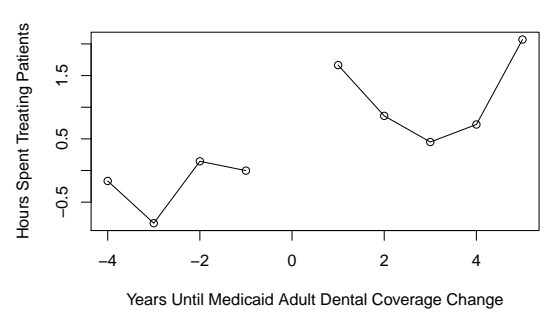

(d) Hours Spent Treating Patients

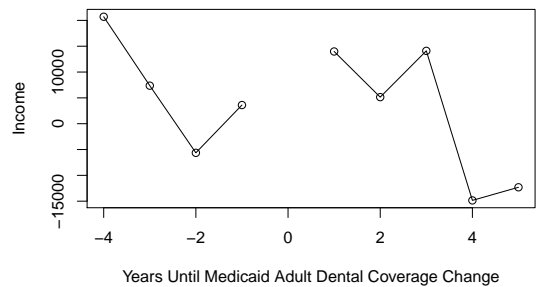

(f) Income from

Primary \& Secondary Practice

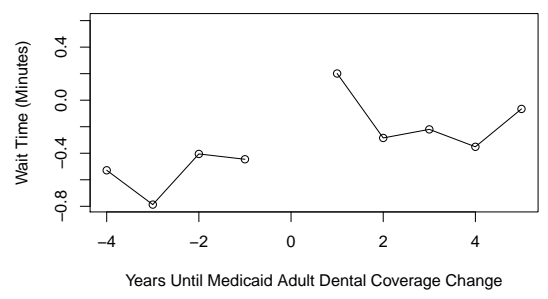

(h) Average \# Minutes in Waiting Room

Note: Graph plots estimates of the change in selected outcomes $t$ years until adult Medicaid dental coverage policy changes (i.e., until full dental coverage for adults is dropped or added). Both states that add (AK, DC, SD) and states that dropped (CA, IN, IA, ME, MN, NM) are included in this figure. Time is ordered such that crossing the 0 position on the $\mathrm{x}$ axis is associated with the indicator for Medicaid full adult dental coverage going from 0 to 1 . We only use the first change for states that both added and dropped Medicaid coverage over the sample period (MA, MI, WA). States that added coverage in 2011, the last year of the sample, are excluded from the figure. 
Appendix Table 1. Alternative Specifications: Other Measures of Dental Coverage

\begin{tabular}{|c|c|c|c|c|}
\hline & Full=1 & Limited $=1$ & Emergency $=1$ & $\begin{array}{c}\mathrm{H} 0: \\
\text { Full=Limited=Emergency }\end{array}$ \\
\hline \multicolumn{5}{|l|}{ Participation } \\
\hline $\begin{array}{l}\text { 1. Any Publicly Insured } \\
\text { Patients }\end{array}$ & $\begin{array}{l}0.09 * * * \\
(0.02)\end{array}$ & $\begin{array}{l}0.06 * * * \\
(0.02)\end{array}$ & $\begin{array}{l}0.05^{* *} \\
(0.02)\end{array}$ & \\
\hline $\begin{array}{l}\text { 2. Percent of Patients Publicly } \\
\text { Insured }\end{array}$ & $\begin{array}{l}2.51 * * * \\
(0.37)\end{array}$ & $\begin{array}{l}1.70 * * * \\
(0.37)\end{array}$ & $\begin{array}{l}1.09 * * \\
(0.45)\end{array}$ & $* * *$ \\
\hline $\begin{array}{l}\text { 3. Percent of Gross Receipts } \\
\text { from Government }\end{array}$ & $\begin{array}{l}2.78 * * * \\
(0.44)\end{array}$ & $\begin{array}{l}1.90^{* * *} \\
(0.45)\end{array}$ & $\begin{array}{c}0.65 \\
(0.69)\end{array}$ & $* * *$ \\
\hline \multicolumn{5}{|l|}{ Visits } \\
\hline 4. Total Visits & $\begin{array}{l}3.39 * * \\
(1.45)\end{array}$ & $\begin{array}{c}0.25 \\
(1.45)\end{array}$ & $\begin{array}{l}-0.74 \\
(1.52)\end{array}$ & $* *$ \\
\hline 5. Emergency/Walk-In Visits & $\begin{array}{l}0.70 * * * \\
(0.18)\end{array}$ & $\begin{array}{c}0.15 \\
(0.18)\end{array}$ & $\begin{array}{c}0.04 \\
(0.27)\end{array}$ & \\
\hline 6. Hygienist Visits & $\begin{array}{l}5.27 * * * \\
(1.90)\end{array}$ & $\begin{array}{c}2.56 \\
(1.85)\end{array}$ & $\begin{array}{c}1.39 \\
(1.85)\end{array}$ & $* *$ \\
\hline $\begin{array}{l}\text { 7. Visits to Publicly Insured } \\
\text { Patients }\end{array}$ & $\begin{array}{l}2.63 * * * \\
(0.55)\end{array}$ & $\begin{array}{l}1.36^{* *} \\
(0.56)\end{array}$ & $\begin{array}{c}0.72 \\
(0.76)\end{array}$ & $* * *$ \\
\hline \multicolumn{5}{|l|}{$\begin{array}{l}\text { Labor Supply, Income and } \\
\text { Hygienist Employment }\end{array}$} \\
\hline $\begin{array}{ll}\text { 8. Hours Spent Treating } \\
\text { Patients per Week } \\
\text { 9. Income from Primary and } \\
\text { Secondary Practice }\end{array}$ & $\begin{array}{c}0.56 * * \\
(0.22) \\
24574 * * * \\
(7554.8)\end{array}$ & $\begin{array}{l}0.29 \\
(0.22) \\
16401.6^{* *} \\
(7540)\end{array}$ & $\begin{array}{c}0.32 \\
(0.27) \\
12819.6 \\
(9955.1)\end{array}$ & \\
\hline 10. Any Hygienist $(0,1)$ & $\begin{array}{l}0.04 * * * \\
(0.01)\end{array}$ & $\begin{array}{c}0.02 \\
(0.02)\end{array}$ & $\begin{array}{c}0.01 \\
(0.01)\end{array}$ & $*$ \\
\hline \multicolumn{5}{|l|}{ Wait Time } \\
\hline $\begin{array}{l}\text { 11. Days until Appt } \\
\text { (Established Patient) }\end{array}$ & $\begin{array}{r}0.73 * \\
(0.37)\end{array}$ & $\begin{array}{l}-0.005 \\
(0.38)\end{array}$ & $\begin{array}{c}0.01 \\
(0.46)\end{array}$ & $*$ \\
\hline $\begin{array}{l}\text { 12. Minutes in Waiting Room } \\
\text { (Established Patient) }\end{array}$ & $\begin{array}{l}0.67 * * * \\
(0.14)\end{array}$ & $\begin{array}{c}0.32 \\
(0.20)\end{array}$ & $\begin{array}{c}0.09 \\
(0.17)\end{array}$ & $* * *$ \\
\hline
\end{tabular}

Notes: Each row presents results from a different regression model. Column (1) reports the estimated coefficient of a variable that equals to 1 if the state offers full dental coverage for adult Medicaid beneficiaries. Column (2) reports the coefficient on a variable that equals to 1 if the state offers limited dental coverage for adult Medicaid beneficiaries. Column (3) reports the coefficient on a variable that equals 1 if the state provides only emergency dental services to Medicaid beneficiaries. All models include state and year fixed effects and practice characteristics (dentist is a general practitioner $(0,1)$, dentist owns the practice $(0,1)$, number of dentists in the practice, number of years practicing), county-level characteristics (unemployment rate, percent black, percent under 18, poverty rate) and state level characteristics (gross state product, percent uninsured). Robust standard errors are clustered by state.

$* * *$ p-value $<.01$ level; **.01< p-value $<.05 ; * .05<\mathrm{p}$-value $<.10$ 
Appendix Table 2. Coefficients on Control Variables for Select Models

\begin{tabular}{|c|c|c|c|c|c|c|}
\hline & $\begin{array}{l}\text { \% Public } \\
\text { Patients }\end{array}$ & $\begin{array}{c}\text { Total } \\
\text { Visits }\end{array}$ & $\begin{array}{c}\text { Emergency/ } \\
\text { Walk-in } \\
\text { Visits }\end{array}$ & $\begin{array}{c}\text { Hrs Spent } \\
\text { Treating } \\
\text { Patients }\end{array}$ & Income & $\begin{array}{c}\text { Any } \\
\text { Hygienist }\end{array}$ \\
\hline \multicolumn{7}{|l|}{ Control variable } \\
\hline General Practitioner & $\begin{array}{l}-1.14^{*} \\
(0.64)\end{array}$ & $\begin{array}{l}-38.80 * * * \\
(1.66)\end{array}$ & $\begin{array}{l}-0.37 * * * \\
(0.11)\end{array}$ & $\begin{array}{l}0.93 * * * \\
(0.10)\end{array}$ & $\begin{array}{l}-106495.2^{* * *} \\
(2771.9)\end{array}$ & $\begin{array}{l}0.34 * * * \\
(0.02)\end{array}$ \\
\hline Owner & $\begin{array}{c}-2.0 * * * \\
(0.39)\end{array}$ & $\begin{array}{l}13.45^{* * *} \\
(0.97)\end{array}$ & $\begin{array}{l}0.52 * * * \\
(0.17)\end{array}$ & $\begin{array}{l}5.44 * * * \\
(0.17)\end{array}$ & $\begin{array}{l}115707.5^{* * * *} \\
(4757.3)\end{array}$ & $\begin{array}{l}-0.08^{* * *} \\
(0.01)\end{array}$ \\
\hline $\begin{array}{l}\text { Number of Dentists } \\
\text { in Practice }\end{array}$ & $\begin{array}{l}0.20^{* *} \\
(0.08)\end{array}$ & $\begin{array}{c}0.27 \\
(0.19)\end{array}$ & $\begin{array}{l}0.17 * * * \\
(0.06)\end{array}$ & $\begin{array}{l}0.08 * * * \\
(0.02)\end{array}$ & $\begin{array}{l}3677.1 * * * \\
(1301.4)\end{array}$ & $\begin{array}{l}0.01 * * * \\
(0.002)\end{array}$ \\
\hline Years Practicing & $\begin{array}{c}-0.07 * * * \\
(0.02)\end{array}$ & $\begin{array}{l}-0.09 * * * \\
(0.03)\end{array}$ & $\begin{array}{l}-0.05 * * * \\
(0.003)\end{array}$ & $\begin{array}{l}-0.12 * * * \\
(0.01)\end{array}$ & $\begin{array}{l}-631.34 * * * \\
(132.8)\end{array}$ & $\begin{array}{l}-0.001 \\
(0.001)\end{array}$ \\
\hline County Poverty Rate & $\begin{array}{c}0.51 * * * \\
(0.05)\end{array}$ & $\begin{array}{l}0.41^{* * *} \\
(0.15)\end{array}$ & $\begin{array}{l}0.09 * * * \\
(0.02)\end{array}$ & $\begin{array}{l}0.03 * * \\
(0.02)\end{array}$ & $\begin{array}{l}-186.06 \\
(477.0)\end{array}$ & $\begin{array}{l}-0.002 * \\
(0.001)\end{array}$ \\
\hline $\begin{array}{l}\text { Fraction Black in } \\
\text { County }\end{array}$ & $\begin{array}{c}-6.30 * * * \\
(0.29)\end{array}$ & $\begin{array}{l}-26.86^{* * * *} \\
(5.86)\end{array}$ & $\begin{array}{l}-1.89 * * * \\
(0.61)\end{array}$ & $\begin{array}{l}-0.45 \\
(0.55)\end{array}$ & $\begin{array}{l}-16731.7 \\
(14154.7)\end{array}$ & $\begin{array}{l}-0.06 \\
(0.07)\end{array}$ \\
\hline $\begin{array}{l}\text { County } \\
\text { Unemployment Rate }\end{array}$ & $\begin{array}{c}0.03 \\
(0.09)\end{array}$ & $\begin{array}{c}0.35 \\
(0.26)\end{array}$ & $\begin{array}{l}0.09 * * * \\
(0.03)\end{array}$ & $\begin{array}{l}-0.01 \\
(0.04)\end{array}$ & $\begin{array}{l}-2276.0 * * \\
(1013.9)\end{array}$ & $\begin{array}{l}-0.001 \\
(0.002)\end{array}$ \\
\hline $\begin{array}{l}\text { Fraction Under } 18 \text { in } \\
\text { County }\end{array}$ & $\begin{array}{c}18.42 * * \\
(8.99)\end{array}$ & $\begin{array}{l}88.85^{* * *} \\
(28.34)\end{array}$ & $\begin{array}{l}9.90 * * * \\
(3.22)\end{array}$ & $\begin{array}{l}5.14^{* *} \\
(1.97)\end{array}$ & $\begin{array}{l}77337.4 \\
(72316.8)\end{array}$ & $\begin{array}{c}0.01 \\
(0.16)\end{array}$ \\
\hline $\begin{array}{l}\% \text { Uninsured in } \\
\text { State } \\
\text { Gross State Product } \\
\text { (in } \$ 100,000 \text { s) }\end{array}$ & $\begin{array}{c}-0.26^{* * *} \\
(0.07) \\
-1.4 \\
(1.7)\end{array}$ & $\begin{array}{l}-0.24 \\
(0.26) \\
5.2 \\
(2.7)\end{array}$ & $\begin{array}{l}-0.05 \\
(0.04) \\
0.38 \\
(0.27)\end{array}$ & $\begin{array}{l}-0.03 \\
(0.04) \\
1.25^{* *} \\
(0.52)\end{array}$ & $\begin{array}{l}-1568.1 \\
(943.4) \\
15095 \\
(24108)\end{array}$ & $\begin{array}{c}0.001 \\
(0.002) \\
1.02 * \\
(0.60)\end{array}$ \\
\hline
\end{tabular}

Notes: Each column presents results from a different regression model. The dependent variable is given in the first row. Independent variables are listed in the first column. All models include state and year fixed effects and an indicator variable for full dental coverage being offered to adult Medicaid beneficiaries. Full model results available for other models upon request. Robust standard errors are clustered by state.

$* * *$ p-value $<.01$ level; $* * .01<$ p-value $<.05 ; * .05<$ p-value $<.10$ 
Appendix Table 3. Inference with Percentile t-Bootstrap

\begin{tabular}{|c|c|c|c|c|}
\hline & $\begin{array}{c}\text { Baseline: } \\
\text { Reduced Form }\end{array}$ & $\begin{array}{c}\text { Baseline: } \\
\text { Instrumental } \\
\text { Variables }\end{array}$ & Reduced Form & $\begin{array}{l}\text { Instrumental } \\
\text { Variables }\end{array}$ \\
\hline \multicolumn{5}{|l|}{ Participation } \\
\hline $\begin{array}{l}\text { 1. Any Publicly Insured } \\
\text { Patients }\end{array}$ & $\begin{array}{l}0.05^{* * *} \\
{[0.02,0.08]}\end{array}$ & $\begin{array}{l}0.005 * * * \\
{[0.002,0.008]}\end{array}$ & $\begin{array}{l}0.05^{* * *} \\
{[0.01,0.07]}\end{array}$ & $\begin{array}{l}0.005^{*} \\
{[-0.001,0.07]}\end{array}$ \\
\hline $\begin{array}{l}\text { 2. Percent of Patients Publicly } \\
\text { Insured }\end{array}$ & $\begin{array}{l}2.28 * * * \\
{[1.33,3.23]}\end{array}$ & $\begin{array}{l}0.23 * * * \\
{[0.14,0.32]}\end{array}$ & $\begin{array}{l}2.28 * * * \\
{[0.64,3.11]}\end{array}$ & $\begin{array}{l}0.23^{* *} \\
{[0.01,0.31]}\end{array}$ \\
\hline
\end{tabular}

Visits

3. Total Visits

$3.36^{* *}$

$[0.48,6.24]$

$0.61 * * *$

$[0.17,1.05]$

5. Hygienist Visits

6. Visits to Publicly Insured Patients

$3.86^{* * *}$

$[1.36,6.35]$

$2.10 * * *$

$[1.26,2.93]$

\section{$0.34 * *$ \\ $[0.06,0.61]$ \\ $0.06 * * *$}

$[0.02,0.11]$

$0.39 * * *$

$[0.15,0.63]$

$0.21 * * *$

$[0.13,0.29]$
$3.36^{* * *}$

$[1.22,7.17]$

$0.61 * * *$

$[0.25,1.24]$

$3.86 * *$

$[1.64,6.63]$

$2.10 * * *$

$[1.18,2.65]$
$0.34^{*}$

$[-0.08,0.72]$

$0.06 * * *$

$[0.01,0.13]$

$0.39 * * *$

$[0.04,0.62]$

$0.21 * * *$

$[0.09,0.28]$

Labor Supply, Income and Hygienist Employment

7. Hours Spent Treating Patients per Week

8. Income from Primary and Secondary Practice

9. Any Hygienist $(0,1)$

$\begin{array}{lc}0.38 * * * & 0.04 * * \\ {[0.08,0.68]} & {[0.01,0.07]} \\ 15427 * * * & 1533.2\end{array}$

[7511,1,23343.3]

$[686.5,2380.0]$

$0.03 * *$

$0.003 * *$

$[0.001,0.06]$

[0.0004, 0.005]
$0.38 * * *$
$[0.10,0.64]$
$15427 * * *$
[4625.2, 23047.5]
$0.03 *$

$0.04 * * *$

$[0.01,0.06]$

\section{Wait Time}

10. Days until Appt (Established Patient)

$0.073 * * \quad 0.07 * *$

$[0.14,1.32]$

$[0.01,0.13]$

$0.73 * * *$

$[0.001,0.16]$

11. Minutes in Waiting Room (Established Patient)

$\begin{array}{cc}0.50 * * * & 0.05 * * * \\ {[0.23,0.78]} & {[0.02,0.08]}\end{array}$

$1533.2 * * *$

[323.3, 2349.2]

$0.003 * *$

$[-0.004,0.047]$

[0.001, 0.005]

Control variables

Notes: Each row presents results from a different regression model. Column (1) reports the estimated coefficient of a variable that equals to 1 if the state offers full dental coverage for adult Medicaid beneficiaries. Column (2) reports the coefficient on a variable that equals to 1 if the state offers limited dental coverage for adult Medicaid beneficiaries. Column (3) reports the coefficient on a variable that equals 1 if the state provides only emergency dental services to Medicaid beneficiaries. All models include state and year fixed effects and practice characteristics (dentist is a general practitioner $(0,1)$, dentist owns the practice $(0,1)$, number of dentists in the practice, number of years practicing), county-level characteristics (unemployment rate, percent black, percent under 18, poverty rate) 
and state level characteristics (gross state product, percent uninsured). Instrumental variables model expresses effect of a 10 percentage point increase in coverage. Confidence intervals computed from a percentile-t bootstrap with 300 replications. ${ }^{* * *}$ p-value $<.01$ level; $* * .01<$ p-value $<.05 ; * .05<$ p-value $<.10$ 


\begin{tabular}{|c|c|c|c|}
\hline & Baseline results & $\begin{array}{l}\text { Geographic } \\
\text { Neighbors }\end{array}$ & $\begin{array}{l}\text { Statistical } \\
\text { Neighbors }\end{array}$ \\
\hline & (1) & (2) & (3) \\
\hline \multicolumn{4}{|l|}{ Participation } \\
\hline 1. Any Publicly Insured Patients & $0.05(0.01) * * *$ & $0.03(0.02)^{* *}$ & $-0.004(0.02)$ \\
\hline $\begin{array}{l}\text { 2. Percent of Patients Publicly } \\
\text { Insured }\end{array}$ & $2.28(0.47) * * *$ & $0.78(0.54)$ & $0.37(0.78)$ \\
\hline $\begin{array}{l}\text { 3. Percent of Gross Receipts } \\
\text { from Government }\end{array}$ & $1.82(0.40)^{* * *}$ & $0.52(0.50)$ & $0.03(0.70)$ \\
\hline \multicolumn{4}{|l|}{ Visits } \\
\hline 4. Total Visits & $3.36(1.43) * *$ & $2.02(1.28)$ & $0.70(1.48)$ \\
\hline 5. Emergency/Walk-In Visits & $0.61(0.22)^{* * *}$ & $0.01(0.17)$ & $0.33(0.20)$ \\
\hline 6. Hygienist Visits (Per Dentist) & $2.22(0.98)^{* * *}$ & $-0.80(8.8)$ & $-1.36(0.82)$ \\
\hline $\begin{array}{l}\text { 7. Visits to Publicly Insured } \\
\text { Patients }\end{array}$ & $2.09(0.42)^{* * *}$ & $0.23(0.49)$ & $0.25(0.67)$ \\
\hline \multicolumn{4}{|l|}{$\begin{array}{l}\text { Labor Supply, Income and Hygienist } \\
\text { Employment }\end{array}$} \\
\hline $\begin{array}{l}\text { 8. Hours Spent Treating Patients } \\
\text { per Week }\end{array}$ & $0.38(0.15)^{* * *}$ & $0.05(0.25)$ & $0.19(0.17)$ \\
\hline $\begin{array}{l}\text { 9. Income from Primary and } \\
\text { Secondary Practice }\end{array}$ & $\begin{array}{c}15427.2 \\
(3941.2)^{* * *}\end{array}$ & $\begin{array}{c}8856.9 \\
(4533.6)^{*}\end{array}$ & $\begin{array}{c}6726.67 \\
(4396.35)\end{array}$ \\
\hline 10. Any Hygienist $(0,1)$ & $0.03(0.01)^{* *}$ & $-0.01(0.02)$ & $-0.02(0.01)$ \\
\hline \multicolumn{4}{|l|}{ Wait Time } \\
\hline $\begin{array}{l}\text { 11. Days until Appt (Established } \\
\text { Patient) }\end{array}$ & $0.73(0.29)^{* *}$ & $0.56(0.35)$ & $0.34(0.38)$ \\
\hline $\begin{array}{l}\text { 12. Minutes in Waiting Room } \\
\text { (Established Patient) }\end{array}$ & $0.50(0.14)^{* * *}$ & $0.29(0.16)^{*}$ & $-0.005(0.24)$ \\
\hline Practice and County-Level Controls? & Yes & Yes & Yes \\
\hline
\end{tabular}

Notes: Each row presents results from a different "placebo" regression model (see text for details). All models include state and year fixed effects. The models in columns (1) and (2) use placebo states based on geographic location. The models in columns (3) and (4) use placebo states based on state characteristics. The models reported in columns (2) and (4) also include practice characteristics (dentist is a general practitioner $(0,1)$, dentist owns the practice $(0,1)$, number of dentists in the practice, number of years practicing), county level covariates (unemployment rate, percent of the population that is black, percent of the population under the age of 18 , and percent in poverty), and state level covariates (gross state product, percent uninsured). Robust standard errors are clustered by state.

$* * *$ p-value $<.01$ level; $* * .01<\mathrm{p}$-value $<.05 ; * .05<\mathrm{p}$-value $<.10$ 


\section{Appendix Table 5. Are the effects of expanding and withdrawing coverage symmetric?}

$\begin{array}{ccc}\text { Effect of } & \text { Effect of } & \text { H0: } \\ \text { Expanding } & \text { Withdrawing } & \text { Effect of Expanding } \\ \text { Coverage } & \text { Coverage } & \text { Coverage }= \\ & & -1 * \text { Effect of Withdrawing } \\ & & \text { Coverage }\end{array}$

Participation

1. Any Publicly Insured Patients

2. Percent of Patients Publicly Insured

Visits

3. Total Visits

4. Visits with Publicly Insured Patients

5. Walk-in Visits

6. Visits with Hygienist (per dentist)

Dentist Labor Supply, Income, Employment Practices

7. Hours Spent Treating Patients per Week

8. Hours Spent Working per Week

9. Income from Practice

10. Any Hygienist $(0,1)$

\section{Wait Times}

$\begin{array}{cl}0.01 & -0.06 * * * \\ (0.03) & (0.02) \\ 0.28 & -2.60 * * * \\ (0.47) & (0.49)\end{array}$

$\begin{array}{cl}0.65 & -3.43 * * \\ (2.83) & (1.46) \\ 0.81 & -2.19 * * * \\ (0.73) & (0.42) \\ 0.59 & -0.75 * * * \\ (0.54) & (0.11) \\ 1.90 * * & -2.17 * \\ (0.75) & (1.29)\end{array}$

0.26

$(0.27)$

$0.59 * *$

$(0.26)$

5450.9

(7583.7)

$0.03 *$

$(0.02)$
$-0.28^{*}$

$(0.16)$

$-0.02$

$(0.22)$

$-18809.4 * * *$

(4431.9)

$-0.03^{*}$

$(0.01)$
11. Days until Appt (Established Patient)
$0.61^{*}$
$-0.60 *$
$(0.33)$
$(0.33)$
12. Minutes in Waiting Room
$0.52 * *$
$-0.50 * * *$ (Established Patient)
$(0.22)$
(0.17)

Notes: Each row presents results from a different regression model. Column (1) reports the estimated coefficient of the independent variable that equals to 1 if the state offers full dental coverage for adults on Medicaid. Column (2) reports the coefficient on the independent variable that equals to 1 if hygienists can bill Medicaid directly for services rendered. Column (3) reports the coefficient on the interaction term of these two variables. All models include state and year fixed effects, practice characteristics (dentist is a general practitioner $(0,1)$, dentist owns the practice $(0,1)$, number of dentists in the practice, number of years practicing), county level covariates (unemployment rate, percent of the population that is black, percent of the population under the age of 18 , and percent in poverty) and state level covariates (gross state product, percent uninsured). Robust standard errors are clustered by state.

$* * *$ p-value $<.01$ level; $* * .01<$ p-value $<.05 ; .05<$ p-value $<.10$ 


\section{Appendix Table 6. Effects of Expansion on Dentists based on Predicted Cost Curves}

$\begin{array}{lccc}\begin{array}{c}\text { Low Probability } \\ \text { "MC-1" or } \\ \text { "MC-2" }\end{array} & \begin{array}{c}\text { High Probability } \\ \text { "MC-1" or "MC-2" }\end{array} & \begin{array}{c}\text { Any Publicly } \\ \text { Insured Patients=1 }\end{array} & \begin{array}{c}\text { Any Publicly } \\ \text { Insured Patients=0 }\end{array}\end{array}$

Visits

1. Total Visits

2. Emergency/Walk-In Visits

3. Hygienist Visits

4. Visits with Publicly Insured Patients

\section{Labor Supply, Income and Hygienist Employment}

5. Hours Spent Treating Patients per Week

6. Income from Primary and Secondary Practice

7. Any Hygienist $(0,1)$

$$
5.13(1.95)^{* * \# \#}
$$$$
0.78(0.30)^{* * \#}
$$

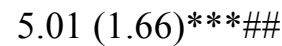

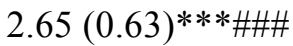

$0.37(0.18)^{* *}$

19291.7

(4085)***\#\#\#

$0.02(0.01)^{*}$
-0.68 (2.27)\#\#

0.03 (0.14)\#

-0.77 (2.05)\#\#

$-0.11(0.40) \# \# \#$

$0.37(0.48)$

-675.9 (6788.4)\#\#\#

$0.04(0.02)$
$5.56(1.83)^{* * * \#}$

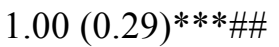

$4.32(2.48)^{*}$

NA
1.24 (1.84)\#

$0.24(0.24) \# \#$

$4.37(1.52)^{* * *}$

NA

\section{Wait Time}

8. Days until Appt (Established Patient)

9. Minutes in Waiting Room (Established Patient)

$$
\begin{array}{cc}
0.82(0.30)^{* * *} & -0.06(0.56) \\
0.61(0.20)^{* * *} & 0.004(0.41)
\end{array}
$$$$
0.84(0.45)^{*}
$$$$
0.61(0.42)
$$

$0.72(0.22) * * * \#$

0.17 (0.24)\#

25282.4

$(5842.2)^{* * * \# \#}$

0.004 (0.02)\#

9439.5 (4716.4)*\#\#

$0.05(0.01)^{* * * \#}$

Control variables

Yes

Yes

Yes

Yes

Notes: Each row presents results from a different regression model. Both columns report the estimated coefficient of a variable that equals to 1 if the state offers full dental coverage for adult Medicaid beneficiaries. The symbol \# indicates significance levels of tests of differences across columns 1 and 2 and columns 3 and 4 . All models include state and year fixed effects and practice characteristics (dentist is a general practitioner $(0,1)$, dentist owns the practice $(0,1)$, number of dentists in the practice, number of years practicing), county-level characteristics (unemployment rate, percent black, percent under 18, poverty rate) and state level characteristics (gross state product, percent uninsured). Robust standard errors are clustered by state.

*** p-value $<.01$ level; ** .01 $<$ p-value $<.05 ; * .05<$ p-value $<.10$ 
Appendix Table 7. Heterogeneous Effects by Relative Reimbursement Rate

\begin{tabular}{|c|c|c|c|}
\hline & Full $=1$ & $\begin{array}{c}\text { Relative } \\
\text { Reimbursement } \\
\text { Rate } \\
\end{array}$ & $\begin{array}{c}\text { Full*Relative } \\
\text { Reimbursement Rate }\end{array}$ \\
\hline \multicolumn{4}{|l|}{ Participation } \\
\hline 1. Any Publicly Insured Patients & $\begin{array}{c}0.029 \\
(0.048)\end{array}$ & $\begin{array}{l}0.125^{* * * *} \\
(0.054)\end{array}$ & $\begin{array}{c}0.018 \\
(0.077)\end{array}$ \\
\hline 2. Percent of Patients Publicly Insured & $\begin{array}{l}3.02 * * \\
(1.17)\end{array}$ & $\begin{array}{l}3.02 * \\
(1.63)\end{array}$ & $\begin{array}{l}-2.90 \\
(1.93)\end{array}$ \\
\hline \multicolumn{4}{|l|}{ Visits } \\
\hline 3. Total Visits & $\begin{array}{l}5.15 \\
(3.59)\end{array}$ & $\begin{array}{l}-1.33 \\
(5.00)\end{array}$ & $\begin{array}{l}-5.06 \\
(6.36)\end{array}$ \\
\hline $\begin{array}{l}\text { 4. Visits with Publicly Insured } \\
\text { Patients }\end{array}$ & $\begin{array}{c}0.93 \\
(1.48)\end{array}$ & $\begin{array}{l}0.45 \\
(2.64)\end{array}$ & $\begin{array}{c}2.02 \\
(3.06)\end{array}$ \\
\hline 5. Visits with Hygienist & $\begin{array}{c}3.94 \\
(3.85)\end{array}$ & $\begin{array}{c}2.48 \\
(5.81)\end{array}$ & $\begin{array}{c}0.71 \\
(7.83)\end{array}$ \\
\hline \multicolumn{4}{|l|}{$\begin{array}{l}\text { Dentist Labor Supply, Income, } \\
\text { Employment Practices }\end{array}$} \\
\hline $\begin{array}{l}\text { 6. Hours Spent Treating Patients per } \\
\text { Week } \\
\text { 7. Income from Practice }\end{array}$ & $\begin{array}{l}-0.60 \\
(0.39) \\
11184 \\
(11248)\end{array}$ & $\begin{array}{l}-0.29 \\
(0.66) \\
28504 \\
(22213)\end{array}$ & $\begin{array}{l}2.00 * * * \\
(0.69) \\
4541 \\
(24215)\end{array}$ \\
\hline 8. Any Hygienist $(0,1)$ & $\begin{array}{c}0.003 \\
(0.025)\end{array}$ & $\begin{array}{c}0.011 \\
(0.042)\end{array}$ & $\begin{array}{c}0.020 \\
(0.057)\end{array}$ \\
\hline \multicolumn{4}{|l|}{ Wait Times } \\
\hline $\begin{array}{l}\text { 9. Days until Appt (Established } \\
\text { Patient) } \\
\text { 10. Minutes in Waiting Room } \\
\text { (Established Patient) }\end{array}$ & $\begin{array}{c}-0.294 \\
(0.948) \\
0.605^{*} \\
(0.304)\end{array}$ & $\begin{array}{l}-0.513 \\
(1.843) \\
1.740^{* *} \\
(0.728)\end{array}$ & $\begin{array}{l}2.75 \\
(1.97) \\
-0.480 \\
(0.573)\end{array}$ \\
\hline
\end{tabular}

Notes: Each row presents results from a different regression model. All models include state and year fixed effects, practice characteristics (dentist is a general practitioner $(0,1)$, dentist owns the practice $(0,1)$, number of dentists in the practice, number of years practicing), county level covariates (unemployment rate, percent of the population that is black, percent of the population under the age of 18 , and percent in poverty) and state level covariates (gross state product, percent uninsured). Robust standard errors are clustered by state.

$* * *$ p-value $<.01$ level; $* * .01<$ p-value $<.05 ; .05<$ p-value $<.10$ 